\title{
PSYCHOLOGICAL CONTRACTS AND DISCRETIONARY BEHAVIOUR IN NIGERIAN ACADEMICS
}

\author{
Mustapha Olanrewaju ALIYU \\ Department of Industrial Relations and Personnel Management, \\ Faculty of Mnagement Sciences, University of Ilorin, Ilorin, Nigeria.

\section{Akeem Ayofe AKINWALE} \\ Department of Employment Relations and Human Resource Management, \\ Faculty of Management Sciences, University of Lagos, Nigeria

\section{Adetunji Oluseyi SHADARE} \\ Department of Employment Relations and Human Resource Management, \\ Faculty of Management Sciences, University of Lagos, Nigeria
}

Received 22. April 2020, Reviewed 05. June 2020, Accepted 30. June 2020

\begin{abstract}
The study explored the relationship between pyshcological contracts and discretionary beahviour in Nigerian academics. The study adopted a survey design and multi-stage cluster sampling to select a proportional sample size of academics in each of the universities, giving a total of 392 an equivalent of $5 \%$ of the population. The study found that the higher the proportion of perceived of BPC, the higher the tendency of DWB and the lower the OCB among academics in Nigeria. Similarly, the experienced BPC by 0.290 and 0.157 , the quality of research would have lower and upper bound of 0.171 and 0.360 and the quality of research will have the lower and upper bound of 0.043 and 0.225 respectively. This implies that the PC had influenced academics in different ways showing a tendency for OCB and DWB. Unfortunately, the tendency for DWB outweighed that of OCB. Academics who uphold OCB despite the perceived BPC should be encouraged to sustain their good behavior.
\end{abstract}

Keywords: Psychological contract, organisational citizenship behaviour, deviant workplace behaviour, Nigeria.

JEL Classification: M55, D23, D91 


\section{Introduction}

Psychological contracts are a set of unwritten expectations about the promises made by employers to employees during the establishment of their employment relationship. These include pleasant and healthy environments, an opportunity for growth and development, healthy relations with co-workers, fair evaluation and appraisal system, grievances fair hearing, acknowledging the innovative ideas, emotional support, equal opportunity for employees' job involvement, job security, among others. Employers, on the other hand, have different expectations from employees. For instance, the employer expects employees' genuineness, promptness, new skills development, hardworking and provision of extra hours as and when required, upholding company reputation, loyalty to the organisation, conformity with rules and regulations, ability to work in a team, tolerate and avoid conflict, commitment for industrial health relations, among others. However, once there is mismatch between what is offered by the employers and what is wanted by the employees, the breach of psychological contract has occurred. That might facilitate the role of employees' emotions and attitudes as driving their behaviour at the workplace, and these behaviour are evident in an employee's job performance (Gavin \& Charlotte, 2013).

Studies revealed that performance is considered a function of employees' workplace attitudes and behaviour (Ajzen, 2015; Dolan \& Lingham 2014; Lia, Wong \& Kim, 2016; Rotundo \& Sackett, 2002). Meanwhile, job performance involves those actions and behaviour that are under the control of the individual, which contribute to the achievement of the organisation's objectives. Two components of overall job performance further revealed; task behaviour and discretionary behaviour. The Organisational Citizenship Behaviour (OCB) and Deviant Workplace Behaviour (DWB) are major forms of discretionary behaviour commonly discussed in the literature (Bambale \& Shamsudin, 2015; Dunlop \& Lee, 2004).

Federal universities in Nigeria are those set up by state and federal governments to provide and promote educational requirements for various states and the country as a whole. These universities have various staff unions that are recognised for effective functioning of the system. Four prominent unions are widely acknowledged within Nigerian public universities. They include, Academic Staff Union of Universities (ASUU), Senior Staff Association of Nigerian Universities (SSANU), National Association of Academic Technologists (NAAT) and Non-Academic Staff Union of Universities (NASU). The primary goal of these unions is to protect the interest and welfare of their members. On ASUU, for example, Iyayi (2018) said that the union an association of academics coming together to regulate the terms and conditions of employment contracts. In achieving these through the guiding principles, ASUU has been at loggerheads with both the university authorities and government. At the level of government, the union has consistently been agitating on three noteworthy issues. These are, funding of the major activities in the university, university autonomy and academic freedom, and conditions of work environment (Adeyemi \& Ekundayo, 2010; Kpolovie \& Obilor, 2013). The issue of funding is the main reasons for industrial actions frequently experienced across the universities in Nigeria

While the understanding of psychological contract is fundamental in every organisation, especially in modern time, it is grossly under-studied in Nigeria, especially in the university environment even of very strong evidence of persistent BPC. For example, ASUU was formed in 1978, following the failure of the Nigerian government to use oil wealth to promote social and economic development (Akinwale, 2014; Iyayi, 2018). Aftermath, several demands were made by ASUU including, 
university autonomy, academic freedom, and other broad national issues. Aside, the recurrent non-payment of arrears of Earned Academic Allowances (EAA), which has led to restiveness in the university environment across Nigeria. In fact, it is one the primary motives for industrial actions that are frequently experienced across Nigerian universities.

It is being alleged that the repressive practices of the Nigerian governments to honour the collective agreement, which is believed to have contributed immensely to the difficulty in exposing academics to training and development (T\&D) locally and internationally. A problem that the management of universities attributes to a shortage of funds. Besides, the academics' strength and provision of basic facilities are not commensurate with the geometric growth in the rate of students' enrolment. The lackadaisical attitude of successive governments towards the implementation of Memorandum of Understandings (MoUs) and Memorandum of Actions (MoAs) is indeed evidence of a BPC, and this may have consequences on the commitment and performances of the academics. Despite the high level of academics' awareness about several instances of exploitation, this development has continued unabated without prior measure. The government in reaction to academics, alleged ASUU of being ungrateful and insatiable, adding that teaching and research have been deteriorated in Nigerian universities (Adekola, 2019; Iyayi, 2018). This on the assumption that academics are high in demand for one right the other, but low in spirit, in addition to the collapsed protocols for recruiting academics.

This further suggests that the formal aspects of psychological contract are unavoidably influenced by informal social interactions. Hence, researching into the psychological contract, its breaches and implications in the Nigerian universities have therefore become necessary and timely, considering the contemporary problems bedevilling universities in Nigeria.

\section{Objectives of the Study}

1. examine the consequences of the discretionary behaviour among the male and female academics of federal universities, Nigeria

2. explore the impact of the breach of psychological contracts on the quality of teaching and research among academics of federal universities, Nigeria

\section{Research Hypotheses}

$\mathrm{H}_{01}$ : The higher the proportion of the perceived breach of psychological contracts, the lower the tendency of deviant workplace behaviour or organisational citizenship behaviour among the male and female academics of federal universities, Nigeria.

$\mathrm{H}_{02}$ : The perceived breach of psychological contracts has no significant impact on the quality of teaching and research among academics of federal universities, Nigeria.

\section{The Concept of Psychological Contract}

Psychological contracts are becoming increasingly important in describing the relationship between employees and the organisations as well as employees' performance, while psychological contract is built on the basis of trust and represents 
that employees believe that the organisations can fulfill their obligations and commitments. The term psychological contract was introduced by Argyris (1960) in order to present the importance of implicit mutual expectations between employees and organisation (Anzam, 2016; Maguire, 2016). Argyris (1960) referred to the psychological contract concept as the employer and employee expectations and mutual obligations of the employment relationship. After Argyris's definition, a significant number of researches were done that developed different perspectives regarding contractual agreement between employee and employer (Blackman \& Benson, 2012; Bolino, Turnley, Lester \& Bloodgood, 2012; Xander, Rob \& Bal, 2011; Xander, 2013).

Later, a revised approach into psychological contract theory was credited to Rousseau (1989) (Dialoke \& Nwakamma, 2016; Rousseau \& Tijoriwala, 1998). Rousseau (1989) goes beyond primary concept. Rousseau (1989) pointed at the unilateral character of the psychological contract as an individual belief regarding the terms and conditions of the reciprocal exchange agreement between the focal person and another party. The terms PC deals with an outline of unwritten beliefs apprehended by the employee and the employer about what each should offer the other, and what each is obligated to provide in the exchange relationship that operates between them (Anderson \& Schalk, 1998; Anzam, 2016; Hairunnisa, Norhidayah, Nur'ain, \& Nurul 2014; Hussein, 2017; Rousseau, 1989, 1995; 2001 Rousseau \& McLean Parks, 1993).

Sounmendu (2016) and Kasenkende (2017) argued that the concept of psychological contract was derived from the social exchange perspective and it explains the working mechanism of employee-employer relationship. It elucidates the mode in which obligations fulfillment affects different factors such as performance or motivation within and beyond the call of duty (Turnley \& Feldman, 2003; Bolino et al. 2012). Umar and Ringim (2015) defined the concept of psychological contracts as an individual's beliefs regarding the terms and conditions of a reciprocal exchange agreement between the focal person and the other party. Her definition focuses on the individual perceptions (about promises made) in the employment relationship. This definition takes into account the fact that both parties do not necessarily have to agree with regard to the terms of the psychological contract (Hannele \& Marjo-Riita 2008; 2010; Nadin \& William 2012).

Rousseau (2001; 2003) argued that the features of a psychological contract include: a) psychological contract reflects an individual's belief(s) in reciprocal obligations between that individual and another party; b) based on reciprocate relationship where one party has paid for an offer a consideration in exchange for an agreement that other party will fulfill its commitments; c) where both the promise and the consideration are highly subjective, i.e. existing in the eye of the beholder, the individual; and d) where nevertheless, the individual holding a belief in a psychological contract attaches to this belief assumptions regarding good faith, fair dealing, and trust, greeting treating this contract as part of the larger fabric of the relationship between the parties. 
Table 1: Forms of the Psychological Contract

\begin{tabular}{|c|c|c|}
\hline Contextual Features & $\begin{array}{l}\text { Type A: Transactional/ } \\
\text { Transitional Contracts }\end{array}$ & $\begin{array}{l}\text { Type B: Relational/ } \\
\text { Balanced Contracts }\end{array}$ \\
\hline Time frame & $\begin{array}{l}\text { Short-term; promises } \\
\text { bounded by time and } \\
\text { space }\end{array}$ & $\begin{array}{l}\text { Long-term; open-ended } \\
\text { and flexibly interpreted } \\
\text { promises }\end{array}$ \\
\hline Degree of specificity & Highly specified & $\begin{array}{l}\text { Loosely specified, } \\
\text { amorphous }\end{array}$ \\
\hline Resources exchanged & $\begin{array}{l}\text { Tangible, having } \\
\text { a monetary value }\end{array}$ & $\begin{array}{l}\text { Intangible, likely to be } \\
\text { socio-emotional }\end{array}$ \\
\hline $\begin{array}{l}\text { Explicitness of promises } \\
\text { exchanged or inferred }\end{array}$ & Explicit & Implicit \\
\hline Approach to negotiation & $\begin{array}{l}\text { Likely to be explicit } \\
\text { and require formal (e.g. } \\
\text { written or handshake) } \\
\text { agreement by both parties }\end{array}$ & $\begin{array}{l}\text { Implicit, and likely } \\
\text { to involve informal } \\
\text { (unspoken?) and/or } \\
\text { assumed agreement by } \\
\text { both parties }\end{array}$ \\
\hline $\begin{array}{l}\text { Examples from HRM } \\
\text { practice }\end{array}$ & $\begin{array}{l}\text { Quantitative calculation: } \\
\text { e.g. a specific rate of } \\
\text { pay offered in exchange } \\
\text { for a specific number of } \\
\text { hours worked and/or } \\
\text { the completion of a set } \\
\text { number of defined tasks }\end{array}$ & $\begin{array}{l}\text { Qualitative calculation: } \\
\text { e.g. an offer of job security } \\
\text { in exchange for an } \\
\text { employee's promise of } \\
\text { loyalty and commitment } \\
\text { to the organisation/task }\end{array}$ \\
\hline
\end{tabular}

Conway and Briner (2007) categorized psychological contracts into two (2) types; Type A and Type B. According to them, Type A contracts tend to emphasise the individual employee's interests and expectations in highly focused, job-specific terms such as working strictly defined hours and working to achieve short-term goals. The emphasis is on an explicit exchange of benefits or goods of short-term value: e.g. cash as opposed to professional development (Zagenczyk, Cruz, Woodard, Walker, Few, Kiazad \& Raja, 2018). The Type A contracts are contrasted with the more Type $\mathrm{B}$ contracts where employees express the expectation to grow in and with a particular organisation because they perceive a mapped out career in their current relationship to an employer (Conway \& Briner, 2007; Boxall \& Purcell, 2003; Zagenczyk et al. 2018).

Aselage and Eisenberger (2003) was on the opinion that employees who harbour a strong belief in their own resourcefulness might be favoured under the Type A contracts. Given that their primary commitment is assumed to be towards leveraging their time-bounded human resource in markets external to the organisation rather than in markets defined within the current boundary of 'the organisation (Varey, 2000; Xander et al. 2011). Furthermore, contrasting these two types of contract implies stretching (e.g. through time) the meanings attributed to trust: e.g. should an employee choose to trust an employer transactionally or transitionally for the short term or relationally or balanced for the long, or both, or neither? 
As a result, once an employee's psychological contract breached, the employment relationship had subsequently been more calculated and transactional, but how far it moved along the continuum was related to the strength of the perceived breach. Responses to violations, particularly in relational contracts, were often found to be severe and that once violated, relational contracts tended to become transactional and self-interested (Satpathy, Patnaik \& Mohanty, 2016). The evidence suggested that behavioural reaction to the breach of psychological contract can be either a function of many interacting variables or a reaction to one issue that had a particularly strong weighting ascribed to it by an employee. Apparently, the different aspect of the contract be it transaction, relational or ideological has a degree of importance attached to it by each employee based on the significance of the element at any given point in his/her career (Aselage \& Eisenberger, 2003; Aliyu, 2019).

Summarily, transactional contract is about short-term duration primarily focused upon the economic exchange with clearly specified roles and responsibilities of each party. Relational contract is about the exchange of social and emotional in exchange for the organisation providing continued T\&D, as well as long-term job security. This type of contract is seen as more valuable for the firm's dependent on employees for their future sustainability as they are encouraged to contribute their commitment and loyalty to the organisation in exchange for their T\&D (Dangmei, 2016; Freese \& Schalk, 2017). Balanced contracts are open-ended arrangements with both parties contributing to each other's learning and development, conditioned on the economic success of the employer. While the transitional contract refers to a state of mind reflecting the consequences of organisational change and transition that is at odds with a previously established employment arrangement, i.e. a disruption to psychological contract and is evidenced in mistrust, uncertainty and an erosion of expectations (Freese \& Schalk, 2017; Rousseau, 1995).

\section{The Concept of Discretionary Behaviour}

Literature revealed that performance is considered as a function of employees' workplace attitudes and behaviour (Bambale \& Shamsudin, 2015; Chen, Yu, Hsu, Lin \& Lou, 2013; Hellriegel \& Slocum, 2011). Meanwhile, job performance involves those actions and behaviour that are under the control of the individual, which contribute to the achievement of the organisation's objectives (Avey et al. 2009; Goodrich \& Palmer, 2015). There are two components of overall job performance; formal tasks i.e. task behaviour and informal tasks i.e. discretionary behaviour (Rotundo \& Sackett, 2002; Palo \& Chawla, 2015; Paul-Titus, 2009). organisational citizenship behaviour (OCB) and deviant workplace behaviour (DWB) are the major forms of discretionary behaviour most commonly found in the literature (Anyim, et al. 2018; Graham, 1991; Dunlop \& Lee, 2004; Iwg, 2017; Naqshbandi \& Kaur, 2017).

The actions of employees' behaviour at a workplace, either good or bad constitute their work behaviour. In an organisation, employees engage either in OCB, which increases organisational effectiveness (Norman, Avey, Nimnicht \& Pigeon 2010), or in DWB which impairs organisational efficiency (Omar, Halim, Zayed, Farhadi, Nasir \& Khairudin, 2016). Implicitly, these behaviour reflect in opposite because the former benefits the organisation while the latter harms it. Originally, Organ (1988) conceptualized the term OCBs as the discretionary behaviour that are exhibited by an individual and not formally recognized by the organisational system which aimed at benefiting the organisation to which the individual belongs (Yang \& Chao, 2016). 
Shore and Tetrick (1994) in Ureeand Parvathy (2015) suggested that psychological contract had three functions: (a) it could reduce insecurity concerns between employees and organisations; (b) it can make employees feel his/her influence in the organisations, namely, employees understand their roles expected by the organisation; (c) it can shape employees behaviour. Since employees will weigh their responsibilities and obligations towards the organisations and make adjustments on their behaviour in responsive to the difference between their responsibilities and obligations expected by their organisations, as the basis of output standard. Thus, employees' perception of breaches of psychological contracts will also have an impact on employees behaviour. Hence, several studies discuss this from the perspective of OCB and DWB (Jex, 2002).

\section{Empirical Review of the Literature}

The findings from the study conducted by Baharuddina et al. (2017) showed a positive relationship between psychological breach contract and employee intention to quit indicated that people tend to quit if they perceived that their organisation do not fulfil their promises and obligation. Meanwhile, psychological contract fulfilment was found to be negatively correlated with intention to quit, suggesting that when employer fulfils their promises and obligation, employee intention to quit is low. It was concluded that, the telecommunication company needs to pay intention in their employment relationship with their employees especially in relation to the commitment as well as obligation.

Divulging on the poor correlation between psychological contract violation and change in behaviour, Tatachari (2017) argue that this might be caused due to the power disparity between employee and employer, which might lead to employees avoiding any display of negative behaviour, as this may result in their plausible redundancy. Furthermore, they believed that employees might have higher commitment for their job than the organisation, this might also play a role in employees overlooking possible violations of their psychological contracts.

Findings from study conducted by Liu et al. (2018) revealed relational psychological contracts did not affect hospitality employees' OCB either; thus, was rejected and the results of the study showed that when hospitality employees in South Korea perceive greater supervisor support, they would demonstrate more organisational citizenship behaviour. However, transactional psychological contract and relational psychological contracts did not have impact on organisational citizenship behaviour of hospitality employees in South Korea. The study concluded that Korean hospitality employees demonstrate more OCBs when they perceive more support from their supervisors and the impact of perceived supervisor support on OCB was still significant for hospitality employees in South Korea.

Findings from Oyelakin and Agu (2017) revealed that the effect of community on relational psychological contract was 0.016 thus, the effect is small. The effect of community on employee turnover intention was 0.019 . Inner life on relational psychological contract was estimated at 0.075 . Inner life on employee turnover intention has 0.021 . Meaningful work has the highest effect of 1.032 on relational psychological contract, while meaningful work has no effect on employees' turnover intention. It was concluded that creating the atmosphere of spirituality in the workplace and having employee's positive attitude to work are critical to encourage employees to stay in an organization. 
The findings from Rafiee et al. (2015) revealed that deviant workplace behaviour has a negative relationship with the staff development $p=32$ and organizational justice as $\mathrm{p}=22$. The findings further show that staff development has a mediating role in the relationship between the organisational justice and deviant workplace behaviour. That is, organisational justice sets grounds for staff development and in turn, staff development reduces the deviant workplace behaviour. It was concluded that, the rate of committing deviant workplace behavior in the university which is very low at 1.5 to 5 on average. Besides, from among the four types of DWB, the highest rate of obliging was witnessed in the procedural deviant and the least one was seen as the political deviant. Similarly, the financial deviant comes second in the list while the interpersonal deviant followed it.

\section{Theoretical Framework}

\section{Theory of Planned Behaviour (TPB)}

The TPB was developed by Ajzen (1985) as an expanded version of the Theory of Reasoned Action (TRA) proposed by Fishbein and Ajzen (1980). The TPB is a cognitive idea of human behaviour that focuses on prediction and understanding of clearly defined behaviour. The theory states that people act by their intentions and perceptions of control over their behaviour, while intentions are influenced by attitudes toward the behaviour, subjective norms, and perceptions of behaviour control (Ajzen \& Fishbein, 2005). Ajzen's (1985) TPB can be broken down into three conceptually independent antecedents leading to behavioural intention (BI): Attitude toward the Behaviour (AAct), Perceived Behavioural Control (PBC) and Subjective Norms (SN) (Ajzen, 2005).

\section{Figure 1: Theory of Planned Behaviour}

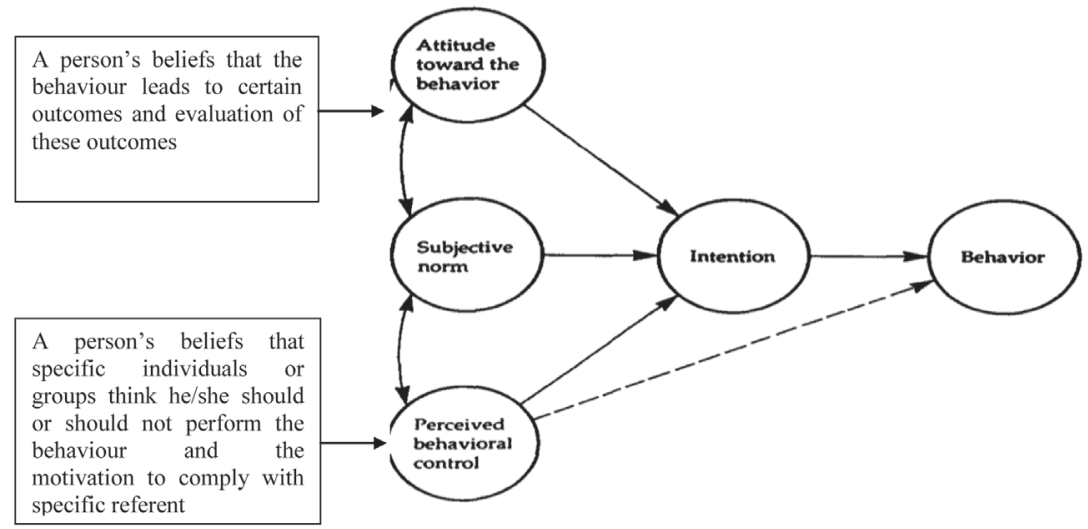

Source: Adapted from Ajzen, I. (2002). The Theory of Planned Behaviour 
TPB further suggested that the behaviour intention directly determines the performance of behaviour. It is assumed that if someone has strong intentions to perform behaviour, there are more chances that his/her performance goes high. The intentions of an employee for psychological contracts can be forecasted with high precision from three antecedents toward their work-related outcomes, behavioural beliefs and attitudes towards the behaviour, normative beliefs and subjective norms, and control believes and perceived behavioural beliefs. The relevance of TPB to this study is that the theory does not rely on external variables, such as emotions or other affected-related constructs (Haunschild, 2015; Tsordia \& Papadimitriou, 2017). It has well-covered an individual's non-volitional behaviour, which incorporates usefulness and easy-to-use as mediating variables. By adding perceived behavioural control, the TPB can explain the relationship between behavioural intention and actual behaviour of employees in a particular organisation.

\section{Expectancy Theory}

Vroom (1964) developed the expectancy theory that an individual will behave or act in a certain way because they are motivated to select a specific behaviour over others due to what they expect the result of that selected behaviour will be. The theory states that human behaviour depends on individual's perception of ideal lifestyle, situations and environment. The components of the theory related to how an individual considers the relationship between human effort, job performance and the rewards arising from such a process. The strength of the attraction of specific results, benefits or rewards for an individual is known as valence. The degree of belief that a specific behaviour will lead to a specific result is called expectancy. Both valence and expectancies are collectively a function of the perception of a circumstance by an individual (Vroom, 1964).

However, individual's expectancy of being promoted may reduce if such individual perceives that promotion is solely dependent on other factors apart from competence and performance. It is important to note that efforts or motivated action take place when an employee thinks that such behaviour would lead to the effective performance of activities or events that will also attract rewards or compensations (Lunenberg, 2011). Hence, this may not be possible through effort alone as other factors such as workers' personal traits such as personality, knowledge, skills, ambition or orientation and perception of his/her roles serve as active criteria (Houston, Meyer \& Paewai, 2006).

Figure 2: Linkages in Expectancy Theory

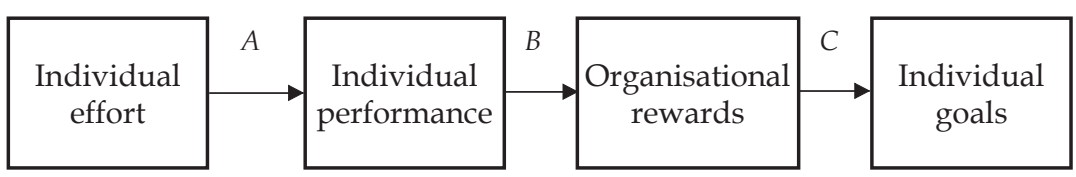

Source: Adapted from Robbins, S. P. E Coulter, M. (2013). Management

Figure 2 explained the effort-performance linkage (expectancy) as the probability perceived by the employee who is using a given amount of effort which will 
lead to a definite level of perfoamcne. The performance-reward linkage (instrumentality) is the degree at which the employee's believes that performing at a particular level is instrumental to achieve the outcome. Similarly, attractiveness of the reward (valence) is considered as goals and the needs of the employees (Robbins \& Coulter, 2013; Robbins \& Judge, 2014).

In summary, expectancy theory was not adequate to explain the circumstances surrounding the psychological contracts. In this case, the theory of planned behaviour was used to explain the contexts of discretionary behaviour from the perspectives of subjective norms, perceived behavioural control and attitudes towards the behaviour. The salient points in the theory of planned behaviour were reinforced by the application of expectancy theory.

\section{Conceptual Framework of the Study}

The conceptual framework of the study describes the behaviour that academics are likely to exhibit depending on how they perceive the management prerogatives. This may flow from the university autonomy, the establishment, the recruitment process, employment contracts and academics freedom. When there is mismatch between what is wanted and what is offered, psychological contract breach may have occurred. The reciprocity will facilitate attitudes towards the BPC. The framework further shows that when academics experience an unfavourable treatment or perceived inequity from their employer, they may reciprocate by engaging in an unproductive and deviant workplace behaviour. Similarly, when academics get a favourable treatment or perceived equity, it is required of them to offer a favourable treatment in return by showing citizenship behaviour. Although, it is assuming that the values and perceptions differ from persons to persons at different times and places. For instance, when the university reneges on its promises or failed to do what they ought to do for the academics, many academics may tend to uphold organisational citizenship behaviour. Figure 3 shows the conceptual framework for the study as follows:

Figure 3: Conceptual Model of the Study

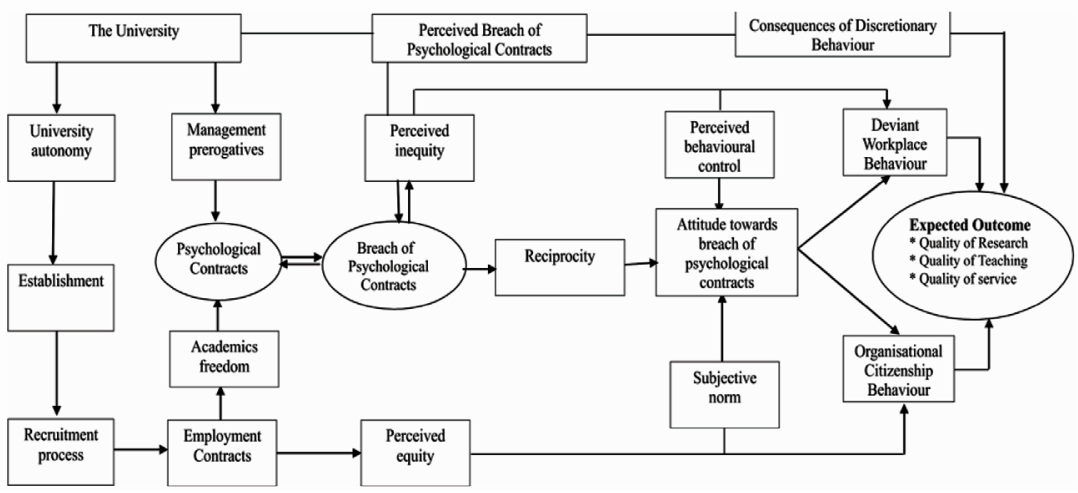

Source: Author's Conceptualization, 2019

Source: Adapted from Robbins, S. P. E Coulter, M. (2013). Management, own processing 


\section{Material and Methods}

The research design adopted for the study was survey design. The design attempts to provide an accurate description or a picture of a particular situation or a phenomenon at one point in time. The study was limited to Federal universities in Nigeria in the six geo-political zones, and only academic staff members who were faculty-based and teach were included in the study. The legitimate population of this study is all academic staff working in selected Federal universities in Nigeria. As at 2017 when this study commenced, there were forty (40) Federal universities spread across the six geo-political zones of the Nigerian Federation (NUC, 2017). The six geopolitical zones are North Central, North East, North West, South East, South West and South-South. Federal universities were chosen for the study because they are the largest government-funded tertiary institutions in Nigeria. So it is assumed that information resources are more likely to be available at these universities. The distribution of the population and sample of the study are presented in Table 2 below

Table 2 Selection of a Proportional Sample from Population of the Study

\begin{tabular}{|c|c|c|c|c|c|c|c|}
\hline 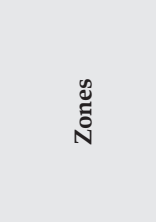 & 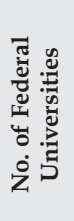 & 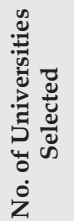 & 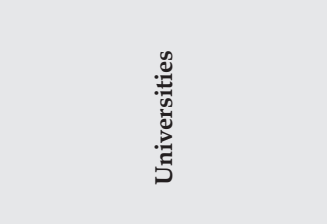 & 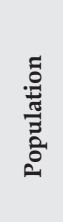 & 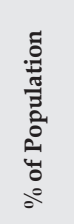 & 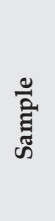 & 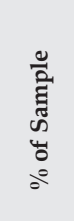 \\
\hline \multirow{2}{*}{$\begin{array}{l}\text { North } \\
\text { Central }\end{array}$} & \multirow{2}{*}{7} & \multirow{2}{*}{2} & University of Ilorin & 1018 & $13 \%$ & 51 & $13 \%$ \\
\hline & & & Federal University, Lokoja & 118 & $2 \%$ & 6 & $2 \%$ \\
\hline \multirow{2}{*}{ North East } & \multirow{2}{*}{6} & \multirow{2}{*}{2} & University of Maiduguri & 886 & $11 \%$ & 44 & $11 \%$ \\
\hline & & & Federal University Gashua & 125 & $2 \%$ & 6 & $2 \%$ \\
\hline \multirow[b]{2}{*}{ North West } & \multirow[b]{2}{*}{9} & \multirow[b]{2}{*}{2} & Bayero University, Kano & 834 & $10 \%$ & 42 & $10 \%$ \\
\hline & & & $\begin{array}{l}\text { Federal University, Birnin } \\
\text { Kebbi }\end{array}$ & 208 & $3 \%$ & 10 & $3 \%$ \\
\hline \multirow{2}{*}{ South East } & \multirow{2}{*}{5} & \multirow{2}{*}{2} & $\begin{array}{l}\text { University of Nigeria, } \\
\text { Nsukka }\end{array}$ & 1511 & $19 \%$ & 75 & $19 \%$ \\
\hline & & & $\begin{array}{l}\text { Federal University, Ndifu- } \\
\text { Alike }\end{array}$ & 189 & $2 \%$ & 9 & $2 \%$ \\
\hline \multirow{2}{*}{ South South } & \multirow{2}{*}{6} & \multirow{2}{*}{2} & University of Port-Harcourt & 1098 & $14 \%$ & 55 & $14 \%$ \\
\hline & & & Federal University, Otuoke & 187 & $2 \%$ & 9 & $2 \%$ \\
\hline \multirow{3}{*}{ South West } & \multirow{2}{*}{7} & \multirow{2}{*}{2} & University of Lagos, Akoka & 1504 & $19 \%$ & 75 & $19 \%$ \\
\hline & & & Federal University, Oye-Ekiti & 203 & $3 \%$ & 10 & $3 \%$ \\
\hline & 40 & 12 & & 7881 & $100 \%$ & 392 & $100 \%$ \\
\hline
\end{tabular}

Sources: Author's Computation, 2017

NUC and Joint Admissions and Matriculation Board, U.T.M.E Brochure, 2019 
A multi-stage cluster sampling technique was employed in this study. This is because it involves two or more steps that combine some of the probability techniques (Sekaran \& Bougie, 2010). The cluster sample technique does not require a sample frame, and it provides convenience for understanding a dispersed study sample (Sekaran \& Bougie, 2010). Firstly, the universities were grouped into the existing six geo-political zones in Nigeria. Secondly, two universities (one from old conventional and one from recently established universities) were randomly selected from each of the six geopolitical zones. The selection resulted in twelve (12) universities. The population of the study stood at 7,881 of only academic staff members. Third, a proportional sample size of academics in each of the universities was selected, giving a total of 392 an equivalent of $5 \%$ of the legitimate population. Determination of sample size for this study is made by referring to the work of Krejcie and Morgan (1970). In their generalized scientific guideline for sample size decisions, Krejcie and Morgan state that the sample size of 392 is appropriate for the study population of up to 2,000 elements. The determined sample of this study is also appropriate for going by the Roscoe's (1975) rule of thumb. Roscoe states that for most research, a sample bigger than 30 and less than 500 is appropriate. Therefore, the sample size of 392 is appropriate based on the rule of thumb. In line with the views of Hill, Brierley and McDougall (2003) who reported that a sample size of 100 and above is sufficient to represent good research findings. Finally, covering all the clusters is undoubtedly going to be very costly and time-demanding. Hence, the choice of simple random sampling technique becomes a good option because of the difficulty to obtain sample frame for administering the study's instrument to select each of the respondents from the quota allotted to each of the faculties in the selected universities

Both primary and secondary data were employed. A structured questionnaire consisting of 34 closed-ended multiple choice-questions were employed for the survey. The instrument comprises of 30 questions related to the three constructs of this study and 4 questions related to socio-demographical variables. The Likert-type scale was used and is considered more appropriate and reliable for measuring the respondents' perception and attitudes (Alreck \& Settle, 1995; Miller, 1991). The researcher, with the assistance of research assistants and Google Doc. Form, distributed copies of the questionnaire to sample elements in various tertiary institutions within Nigeria. Follow-ups using personal contact, telephone and email were done to ensure timely completion and collection of distributed copies of the questionnaire. Secondary data were obtained from relevant authorities such as National Bureau of Statistics, internet search engines, Google Scholar, Academia.edu, Research Gate, Sage, E.B.S.C.O., Encyclopedia Britannica, among others. Upon completion of data collection, a combination of both descriptive and inferential statistics were employed as methods of data analysis. Linear regression was employed to analyze relationships among construct variables through the use of Statistical Package for Social Sciences (SPSS) v20.

\section{Results and debate}

The statistics in Table 3 shows each level of the model construct, the mean rankings on the consequences of discretionary behaviour by male and female academics of federal universities, Nigeria. Since the constructs on consequences of discretionary behaviour take on the rating scale between 1 (very poor) and 10 (excellent). The mean $(\mu)$ is equal to the proportion of respondents who agreed on the statement on the reverse scale ratings. The statistic column shows the values usually produced by frequencies, 
using the dataset produced by the bootstrapping algorithms. The parametric mean ( 7.3522) was found between the pendulum of the bootstrap confidence interval for the mean $7.1320<\mu<7.5694$ and the standard error ( $\mathrm{s} . \mathrm{e}=0.10191$ ), suggested that academic staff is rated good for making themselves available for other responsibilities in the university aside from teaching. This presupposes means that the organisational control is rated well among academic in the selected universities. Also, result equally show that the degree and extent of availability of employees for official duty were rated extremely good with sample mean ( 7.9045$)$ found between the pendulum of the bootstrap confidence interval for the mean $7.6574<\mu<8.1245$ and the standard error mean of 0.1145 . This presupposes means that the selected respondents have a very good rating in organisational trusts.

Table 3: Consequences of the Discretionary Behaviour among the Male and Female Academics of Federal Universities

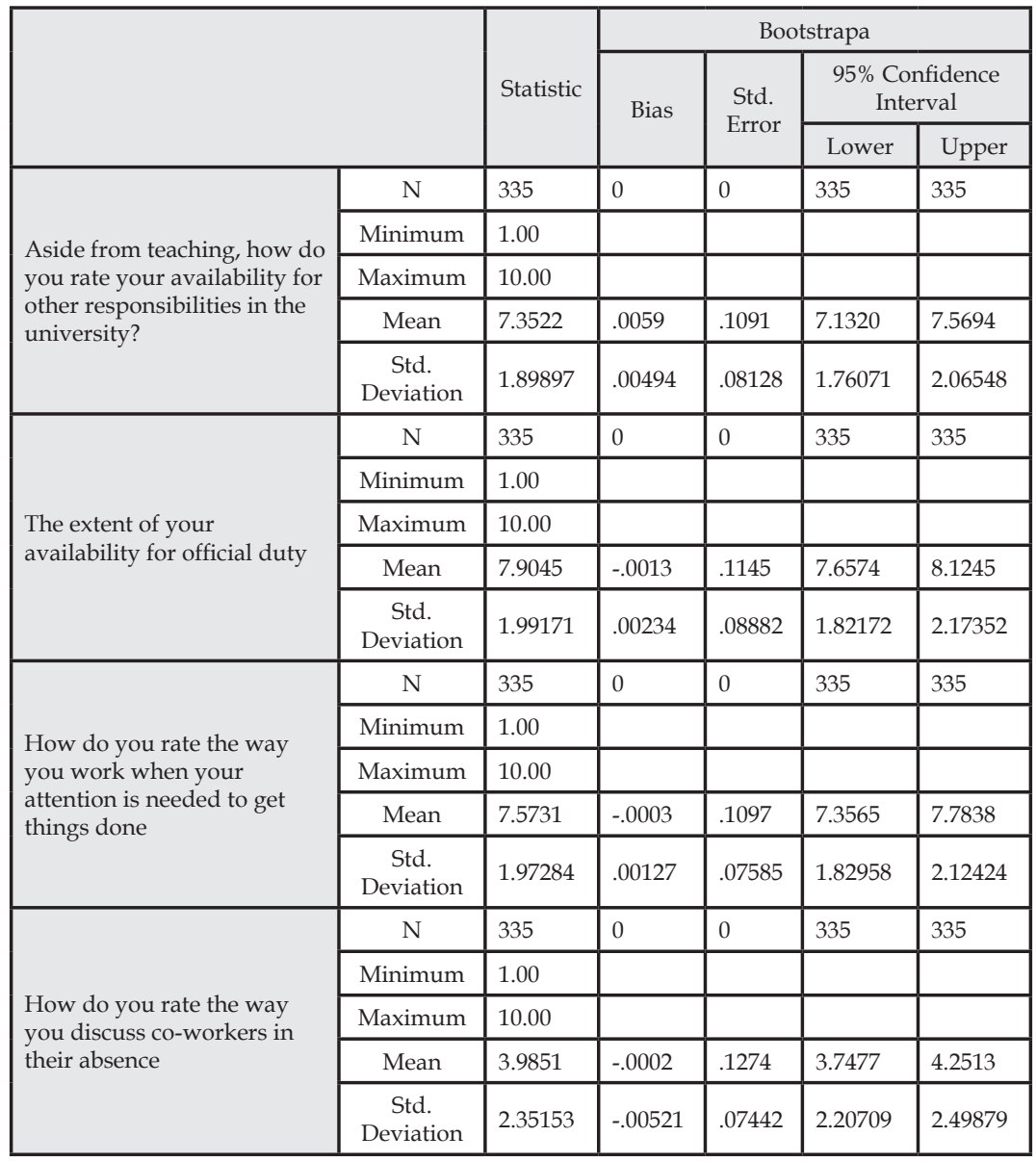




\begin{tabular}{|c|c|c|c|c|c|c|}
\hline \multirow{5}{*}{$\begin{array}{l}\text { How do you rate lecturer- } \\
\text { students relationship in your } \\
\text { department }\end{array}$} & $\mathrm{N}$ & 335 & 0 & 0 & 335 & 335 \\
\hline & Minimum & 1.00 & & & & \\
\hline & Maximum & 10.00 & & & & \\
\hline & Mean & 6.9075 & .0068 & .1233 & 6.6723 & 7.1600 \\
\hline & $\begin{array}{c}\text { Std. } \\
\text { Deviation }\end{array}$ & 2.14736 & -.00244 & .08582 & 1.96459 & 2.31597 \\
\hline \multirow{5}{*}{$\begin{array}{l}\text { How well are you able } \\
\text { to encourage students to } \\
\text { pursue their career? }\end{array}$} & $\mathrm{N}$ & 335 & 0 & 0 & 335 & 335 \\
\hline & Minimum & 1.00 & & & & \\
\hline & Maximum & 10.00 & & & & \\
\hline & Mean & 7.3851 & .0037 & .1230 & 7.1463 & 7.6291 \\
\hline & $\begin{array}{c}\text { Std. } \\
\text { Deviation }\end{array}$ & 2.11023 & -.00070 & .09714 & 1.89846 & 2.29477 \\
\hline \multirow{5}{*}{$\begin{array}{l}\text { How well are you able to } \\
\text { supervise students }\end{array}$} & $\mathrm{N}$ & 335 & 0 & 0 & 335 & 335 \\
\hline & Minimum & 1.00 & & & & \\
\hline & Maximum & 10.00 & & & & \\
\hline & Mean & 7.5522 & .0062 & .1189 & 7.3457 & 7.8202 \\
\hline & $\begin{array}{c}\text { Std. } \\
\text { Deviation }\end{array}$ & 2.02443 & -.00612 & .09245 & 1.83805 & 2.20096 \\
\hline Valid N (listwise) & $\mathrm{N}$ & 335 & 0 & 0 & 335 & 335 \\
\hline
\end{tabular}

a. Unless otherwise noted, bootstrap results are based on 335 bootstrap samples

Source: Survey, 2019

The significant of the relationship between the breach of psychological contracts and the quality of teaching and research were captured by six constructs which critically assess whether there is an association between the variables. This is to establish whether there is no personal interest or bias in the opinion of respondents regarding the breach of psychological contract and its association with quality of teaching and research among academics of federal universities, Nigeria.

Table 4: Mean Measure of Perceived BPC by Educational Background and Quality of Teaching and Research

\begin{tabular}{|l|c|c|c|c|c|}
\hline Constructs & $\begin{array}{c}\text { HND/ } \\
\text { B.Sc. }\end{array}$ & $\begin{array}{c}\text { GDM/ } \\
\text { PGDE }\end{array}$ & $\begin{array}{c}\text { MA/ } \\
\text { M.Sc. } \\
\text { MPA }\end{array}$ & PhD & Others \\
\hline $\begin{array}{l}\text { Current results of the undergraduate } \\
\text { students in your favourite course }\end{array}$ & 7.56 & 6.85 & 5.98 & 6.76 & 6.89 \\
\hline $\begin{array}{l}\text { How well are you able to supervise } \\
\text { students }\end{array}$ & 7.39 & 6.31 & 7.21 & 7.8 & 7.78 \\
\hline $\begin{array}{l}\text { How well are you able to have co-written } \\
\text { article(s) with research students in local } \\
\text { journals? }\end{array}$ & 7.11 & 5.62 & 6.16 & 6.94 & 5.89 \\
\hline $\begin{array}{l}\text { How well are you able to have co-written } \\
\text { article(s) with research students in foreign } \\
\text { journals? }\end{array}$ & 4.94 & 3.69 & 5.01 & 6.3 & 5.89 \\
\hline
\end{tabular}




\begin{tabular}{|l|c|c|c|c|c|}
\hline $\begin{array}{l}\text { Rate the quality of your publication in local } \\
\text { journals }\end{array}$ & 6.89 & 7.15 & 6.82 & 7.86 & 7.11 \\
\hline $\begin{array}{l}\text { Rate the quality of your publication in } \\
\text { foreign journals }\end{array}$ & 4.83 & 6.77 & 5.98 & 7.83 & 6.89 \\
\hline Total & 38.72 & 36.39 & 37.16 & 43.49 & 40.45 \\
\hline
\end{tabular}

Source: Survey, 2019

The mean measure of the perceived BPC according to educational background and the quality of teaching and research in the Table 4 revealed that proportion of the perceived breach of psychological contract by academics' educational qualification and the quality of the teaching and research. Despite the perceived BPC of PhD degree or equivalent, they are likely to perform better in term of teaching and research compare with others without PhD. Similarly, those with $\mathrm{PhD}$ degrees or equivalent are compared to perceived breach of psychological contracts in the federal universities.

\section{Test of Hypotheses}

Hypothesis One $\left(\mathrm{H}_{01}\right)$ : The higher the proportion of the perceived BPC, the lower the tendency of DWB or OCB among the male and female academics of federal universities in Nigeria.

Table 5: 2-Way ANOVA of the BPC on DWB or OCB among Male and Female Academics of Federal Universities

\begin{tabular}{|l|c|c|c|c|c|}
\hline Source & $\begin{array}{c}\text { Type III } \\
\text { Sum of } \\
\text { Squares }\end{array}$ & Df & $\begin{array}{c}\text { Mean } \\
\text { Square }\end{array}$ & F & Sig. \\
\hline Corrected Model & $217.917 \mathrm{a}$ & 41 & 5.315 & 13.207 & .000 \\
\hline Intercept & 63.903 & 1 & 63.903 & 158.787 & .000 \\
\hline BPC/DWB & .977 & 4 & .244 & .607 & .000 \\
\hline BPC/OCB & 6.787 & 1 & 6.787 & 16.863 & .658 \\
\hline Gender/DWB & 55.548 & 4 & 13.887 & 34.507 & .000 \\
\hline Gender/OCB & .001 & 1 & .001 & .001 & .970 \\
\hline Error & 117.916 & 293 & .402 & & \\
\hline Total & 5311.000 & 335 & & & \\
\hline Corrected Total & 335.833 & 334 & & & \\
\hline
\end{tabular}

Dependent Variable: DWB/OCB

a. $R$ Squared $=.649$ (Adjusted $R$ Squared $=.600)$

Source: Survey, 2019

The Table 5 shows that all variables between-subject effects are jointly significant, for instance, BPC and DWB (F-ratio $=0.607, \mathrm{p}$-value $=0.000<0.05$ ), gender and DWB (F-ratio $=34.507$, p-value $=0.000<0.05$ ) except BPC and OCB (F-ratio=16.863; $\mathrm{p}$-value $=0.658>0.05)$; gender and OCB (F-ratio; $\mathrm{p}$-value $=0.970>0.05)$. This implies that 
there are elements that when academics perceived BPC, some academics may tend to uphold OCB.

Table 6: Multiple Comparisons Coefficient

\begin{tabular}{|c|c|c|c|c|c|c|c|c|}
\hline \multicolumn{3}{|c|}{ Variables } & BPC1 & BPC2 & DWB1 & DWB2 & OCB1 & ОСВ2 \\
\hline \multicolumn{3}{|c|}{ Mean Differences } & 30.793 & 20.504 & 22.666 & 8.308 & 20.635 & 17.404 \\
\hline \multicolumn{3}{|l|}{ Df } & 9 & 9 & 9 & 9 & 9 & 9 \\
\hline \multicolumn{3}{|c|}{ Asymp. Sig. } & .000 & .015 & .007 & .503 & .007 & .043 \\
\hline \multirow{3}{*}{$\begin{array}{l}\text { Tukey } \\
\text { Sig. }\end{array}$} & Sig. & $.000 \mathrm{c}$ & $.021 \mathrm{c}$ & $.006 \mathrm{c}$ & $.475 c$ & $.003 c$ & $.036 c$ & \\
\hline & \multirow{2}{*}{$\begin{array}{l}95 \% \\
\text { Confidence } \\
\text { Interval }\end{array}$} & $\begin{array}{l}\text { Lower } \\
\text { Bound }\end{array}$ & .000 & .006 & .000 & .421 & .000 & .016 \\
\hline & & $\begin{array}{l}\text { Upper } \\
\text { Bound }\end{array}$ & .009 & .036 & .014 & .528 & .009 & .056 \\
\hline
\end{tabular}

Based on observed means.

The error term is Mean Square(Error) $=.984$.

*. The mean difference is significant at the 05 level.

The group sizes are unequal. The harmonic mean of the group sizes is used. Type I error levels are not guaranteed.

Alpha $=.05$

Source: Survey, 2019

Table 6 further revealed the multiple comparisons coefficient to show that the result of this test provides a concise, comprehensive view that the higher the proportion of the perceived BPC1 $(\mathrm{MD}=30.793)$ the higher the tendency of DWB1 $(\mathrm{MD}=22.666)$ and the lower the OCB1 $(\mathrm{MD}=20.635)$. Conversely, the lower the proportion of the perceived BPC2 (MD=20.504), the lower the tendency of DWB2 (MD=8.308) and the higher the tendency of OCB2 $(\mathrm{MD}=17.404)$. Therefore, the data supported the null hypothesis that the higher the proportion of perceived of $\mathrm{BPC}$, the higher the tendency of DWB and the lower the OCB. Conversely, the lower the proportion of perceived BPC, the lower the tendency of DWB and the higher the tendency of OCB among academics of federal universities in Nigeria.

Hypothesis Two (H02): The perceived breach of psychological contracts has no significant impact on the quality of teaching and research among academics of federal universities in Nigeria. 
Table 7: Regression of the impact of psychological contracts breaches on the quality of teaching and research in federal universities

\begin{tabular}{|c|c|c|c|c|c|c|c|c|}
\hline \multicolumn{9}{|c|}{ Coefficientsa } \\
\hline & \multirow{2}{*}{ Model } & \multicolumn{2}{|c|}{$\begin{array}{l}\text { Unstandardized } \\
\text { Coefficients }\end{array}$} & \multirow{2}{*}{$\begin{array}{c}\begin{array}{c}\text { Standardized } \\
\text { Coefficients }\end{array} \\
\text { Beta }\end{array}$} & \multirow{2}{*}{$t$} & \multirow{2}{*}{ Sig. } & \multicolumn{2}{|c|}{$\begin{array}{l}95.0 \% \text { Confidence Interval } \\
\text { for B }\end{array}$} \\
\hline & & B & $\begin{array}{l}\text { Std. } \\
\text { Error }\end{array}$ & & & & $\begin{array}{l}\text { Lower } \\
\text { Bound }\end{array}$ & Upper Bound \\
\hline & (Constant) & 2.712 & .160 & & 16.934 & .000 & 2.397 & 3.027 \\
\hline 1 & $\begin{array}{l}\text { Breach of } \\
\text { Psychological } \\
\text { Contracts and } \\
\text { Quality of } \\
\text { Teaching }\end{array}$ & .265 & .048 & .290 & 5.538 & .000 & .171 & .360 \\
\hline & (Constant) & 3.533 & .155 & & 22.855 & .000 & 3.229 & 3.837 \\
\hline 2 & $\begin{array}{l}\text { Breach of } \\
\text { Psychological } \\
\text { Contracts and } \\
\text { Quality of } \\
\text { Research }\end{array}$ & .134 & .046 & .157 & 2.895 & .004 & .043 & .225 \\
\hline
\end{tabular}

Table 7 shows an estimated regression equation indicates that BPC has a significant effect on the quality of teaching, as evidenced by their coefficient value of $\mathrm{t}=(\mathrm{B}=0.290, \mathrm{p}=0.000)=16.934$. Also, results indicate a significant effect of BPC on the quality of research with a coefficient value of $t=(0.157, p=0.000)=22.855$. Conversely, dependent variables, such as current results of the undergraduate students, able to encourage students to pursue their career, able to supervise students, co-written article(s) with research students in local and foreign journals, quality of publication in local and foreign journals reflect $t=5.538$ and $t=2.895$ respectively. The results indicated that experienced BPC by 0.290 and 0.157 , the quality of research would have lower and upper bound of 0.171 and 0.360 respectively and the quality of research will have the lower and upper bound of 0.043 and 0.225 respectively, which is significant while keeping other variables constant. However, all elements of BPC are jointly significant with qualities of teaching and research. The p-values are less than the designated alpha level at $5 \%$. i.e. p-values $=0.000<0.05$. The data did not support the null hypothesis, and thus, the perceived breach of psychological contracts have a significant impact on the quality of teaching and research among academics of federal universities in Nigeria.

\section{Conclusion}

The study discovered that the BPC had influenced academics in different ways showing a tendency for OCB and DWB. Unfortunately, the tendency for DWB outweighed that of OCB. For instance, when the university reneges on its promises or failed to do what they ought to do for the academics, many academics may react negatively by engaging in deviant behaviour such as abuse of teaching hours, misuse of official vehicles, internet, failure to attend statutory meetings, sexual harassment, 
plagiarism among others. Conversely, when the university fails to uphold the promises made to the academics, results showed that some academics might tend to uphold organisational citizenship behaviour such as promoting the image of their university, help colleagues in resolving issues, working longer days, punctuality, showing tolerance, among others. The study therefore recommends that the academics who uphold OCB despite the perceived BPC should be encouraged to sustain their good behavior and the universities should provide academics with the necessary resources and incentive. This will increase academics' organisational citizenship behaviour and reduce the tendency for deviant workplace behaviour in federal universities.

\section{Bibliography}

1. Adekola, B. (2019). Professional university administration in Nigeria and the realities of political and economic challenges. Distinguished lecture delivered to mark 60th Birthday Anniversary of Dr Omojola Awosusi, Ekiti State University, Ado-Ekiti, January 14th 2019.

2. Adeyemi, T. O., \& Ekundayo, H. T. (2010). Managing students' crisis in tertiary institutions in Nigeria. Journal of Research in National Development, 8(1), $102-$ 114.

3. Ajzen, I. \& Fishbein, M. (2005). Attitude behaviour relations: A theoretical analysis and review of empirical research. Psychological Bulletin, 84, 888-918.

4. Ajzen, I. (1985). Perceived behavioural control, self-efficacy, locus of control, and the theory of planned behaviour. Journal of Applied Social Psychology, 32, 665683.

5. Ajzen, I. (2002). Residual effects of past on later behaviour: Habituation and reasoned action perspectives. Personality and Social Psychology Review, 6, 107122.

6. Ajzen, I. (2015). Consumer attitudes and behaviour: The theory of planned behaviour applied to food consumption decisions. Rivista di Economia Agraria, 70(2), 121-138.

7. Akinwale, A. A. (2014). Precarious working conditions and exploitation of workers in the Nigerian informal economy. Philippine Social Science Diliman, 10(1), 117146

8. Aliyu, M.O. (2019). Breach Of Psychological Contracts And Discretionary Behaviours Among Academic Staff In Nigerian Universities. Proceedings of the International Conference on Industrial Engineering and Operations Management Riyadh, Saudi Arabia, November 26-28, 2019. Pp859-868. http://www. ieomsociety.org/gcc2019/proceedings/

9. Anderson, N. \& Schalk, R. (1998). The psychological contract in retrospect and prospect. Journal of Organisational Behaviour, 19(1), 637-647.

10. Anyim, F. C., Obisi, C. \& Aliyu, M. O. (2018). Deviant workplace behavour in Nigeria: A conceptual and empirical analysis. Ilorin of Journal of Human Resource Management, 2(1), 73-88

11. Anzam, M. (2016). Perceptions and impact of psychological contract breach among bank employees in Bangladesh. Responsibilities and Rights Journal, 2(2), 121-139.

12. Aselage, J. \& Eisenberger, H. (2003). Perceived organisational support and psychological contracts: A theoretical integration. Journal of Organisational Behaviour, 24(1), 491-509. 
13. Avey, J. B., Avolio, B. J., Crossley, C. D., \& Luthans, F. (2009). Psychological ownership: Theoretical extensions, measurement and relation to work outcomes. Journal of Organisational Behaviour, 30, 173-191.

14. Baharuddina, S. S., Ruzainy, M. N., Asyraf, M. A. Omara, N. E. \& Ismail, N. A. (2017). Psychological contract breach and psychological contract fulfilment on employee intention to quit. International Journal of Business Management, 2(1), 50-58.

15. Bambale, J. A. \& Shamsuddin, S. A. (2015). Psychological factors as predictors of turnover intention among employees of post consolidation banks in Nigeria. European Scientific Journal, 8(20), 81-95.

16. Blackman, D. A. \& Benson, A. M. (2012). The role of the psychological contract in managing research volunteer tourism. Journal of Travel \& Tourism Marketing, 27(1), 221-235.

17. Bolino, M. C., Turnley, W. H., Lester, S. W. \& Bloodgood, J. M. (2012). The impact of psychological contract fulfillment on the performance of in-role and organisational citizenship behaviour. Journal of Management, 29(2), 187-206.

18. Boxall, P. \& Purcell, J. (2003). Strategy and human resource management. Basingstoke, U.K: Palgrave Macmillan.

19. Chen, C. C., Chen, M. Y., \& Liu, Y. C. (2013). Negative affectivity and workplace deviance: The moderating role of ethical climate. International Journal of Human Resource Management, 24(15), 2894-2910.

20. Conway, N. \& Briner, R. B. (2007). A daily diary study of affective responses to psychological contract breach and exceeded promises. Journal of Organisational Behaviour, 23(2), 287-302.

21. Dangmei, J. (2016). Psychological contract: Why should employers care about it in the 21st century? International Journal of Management and Social Science Research Review, 1(5), 187-190.

22. Dialoke, I. and Nwakamma, C. N. (2016). Psychological contract and manpower development in Nigeria. International Journal of Advanced Academic Research, 2(12), 57-72.

23. Dolan, S. \& Lingham, T. (2014). Fundamentals of International Organisational Behaviour. New Delhi: Prentice Hall Inc.

24. Dunlop, P. D.\& Lee, K. (2004). Workplace deviance, organisational citizenship behaviour, and business unit performance: The bad apples do spoil the whole barrel. Journal of Organisational Behaviour, 25(1), 67-80.

25. Freese, C. \& Schalk, R. (2017). How to measure the psychological contract? A critical criteria-based review of measures. South African Journal of Psychology, 38(2), 269-286.

26. Gavin, P. M., \& Charlotte, R. (2013). Negative interpersonal behaviour at work: An evidence based classification of workplace bullying. International Journal of Psychology and Behavioural Sciences, 3(4), 95-108.

27. Hairunnisa, M., Norhidayah, M. R., Nur'ain, A. \& Nurul, A. Z. (2014). Understanding employee psychological contract and job satisfaction. Global Journal of Business and Social Science Review, 2(4), 112 - 118.

28. Hannele, S. \& Marjo-Riitta, P. (2008). Employee agency: Challenges and opportunities for psychological contract theory. Personnel Review, 37(5), 473-489.

29. Hellriegel, D. \& Slocum, J. W. (2011). Organisational behaviour. 13th edition. USA: South-Western Cengage Learning.

30. Hill, H., Birley, G. \& McDougall, E. (2003). Research methods and statistics in psychology, 3rd edition. London: Hoder and Stoughton Limited 
31. Iwg, S. (2017). Commitment and competency as an organisational citizenship behaviour predictor and its effect on the performance. International Journal of Economics, Commerce and Management, 3(1), 1-13.

32. Iyayi, O. (2018). Experience and reactions to psychological contract breach among Nigerian University academics. Covenant Journal of Business \& Social Sciences, 9(1), 30-44.

33. Kpolovie, P. J. \& Obilor, I. E. (2013). Adequacy inadequacy: Education funding in Nigeria. Universal Journal of Education and General Studies, 2(8), 239-254.

34. Lia, J., Wong, K. A. \& Kim, W. G. (2016). Effects of psychological contract breach on attitudes and performance: The moderating role of competitive climate. International Journal of Hospitality Management, 5(1), 1-10.

35. Maguire, H. (2016). The changing psychological contract: Challenges and implications for HRM, organisations and employees. Journal of Applied Social Psychology, 34(8), 161 7-1 637.

36. Nadin, S. J. \& Williams, C. C. (2012). Psychological contract violation beyond an employees' perspective: The perspective of employers. Employee Relations Review, 34(2), 110-125.

37. Naqshbandi, M. N. \& Kaur, S. (2017). A study of organisational citizenship behaviour, organisational structures and open innovation. Centre for Promoting Ideas, 1(2), 182-193.

38. Nigerian Universities Commission (NUC) (2018). List of Nigerian universities. Retrieved from: https:/ / nuc.edu.ng/nigerian-univerisities/federal-univeristies/

39. Norman, M. S., Avey, J. B., Nimnicht, J. L. \& Pigeon, N. G. (2010). The interactive effects of psychological capital and organisational identity on employee organisational citizenship and deviance behaviour, Organisational Studies, 17(4), $380-391$.

40. Omar, F., Halim, F. W., Zayed, A. Z., Farhadi, H, Nasir R. \& Khairudin, R. (2016). Stress and job satisfaction as antecedents of workplace deviant behaviour. Worlds Applied Sciences Journal, 12(2), 46-51

41. Oyelakin, O. \& Agu, G. A. (2017). A mediating role of relational psychological contract on the relationship between work place spirituality and employee turnover intention in Nigeria banks. American Journal of Applied Psychology, 6(4), 75-82.

42. Palo, S., \& Chawla, A. (2015). Incidences of workplace deviance behaviour among nurses. Indian Journal of Industrial Relations, 51, 150-161

43. Paul-Titus, R. (2009). Deviant workplace behaviour in organisations: Antecedents, influences, and remedies. Journal of Social and Psychological Sciences for Human Development, 12(1), 46-51.

44. Rafiee, M., Hoveida, R. \& Rajaeipoor, S. (2015). The relationship of the deviant workplace behaviour with the organisational justice and staff development in the Universities of Tehran. International Journal of Human Resource Studies, 5(1), 126-140.

45. Rotundo, M., \& Sackett, P. R. (2002). The relative importance of task, citizenship, and counterproductive performance to global ratings of job performance: A policy-capturing approach. Journal of Applied Psychology, 87(2), 66-80.

46. Rousseau, D. M. \& Tijoriwala, S. (1998). Assessing psychological contracts: Issues, alternatives and measures. Journal of Organisational Behaviour, 19(1), 679-695.

47. Satpathy, I., Patnaik, B. C. \& Mohanty, S. (2016). Decoding the other side of psychological contract. International Journal of Research in Economics and Social Sciences, 6(5), 165-174. 
48. Tatachari, S. (2017). Dynamics of organisational identification, psychological contract breach and prestige during early socialization Srinivasan Tatachari. Retrieved from: http:/ / ssrn.com/abstract $=2378234$

49. Turnley, W. \& Feldman, D. (2003). The impact of psychological contract violations on exit, voice, loyalty and neglect. Human Relations, 52(7), 895-922.

50. Umar, S. \& Ringim, K. J. (2015). Influence of psychological contract on employee turnover intention among Nigerian employees. Journal of Applied Psychology, 68(1), 655-663.

51. Varey, R. J. (2000). A broader conception of internal marketing: A social constructionist approach. Singapore: Lewis \& Varey

52. Xander, D. L., Rob, J. B. \& Bal, P. M. (2011). Psychological contract and organisational citizenship behaviour: A new deal for new generations? Advances in Hospitality and Leisure, 7(1), 109-130.

53. Xander, L. (2013). Generations and their psychological contracts. Tilburg, Tanzania: Ipskamp Drukkers

54. Zagenczyk, T. J., Cruz, K. S., Woodard, A. M., Walker, J. C., Few, W. T., Kiazad, K. \& Raja, M. (2018). The moderating effect of machiavellianism on the psychological contract breach-organisational identification/disidentification relationships. Journal of Business and Psychology, 28(3), 287-299.

\section{Correspondence address:}

Mr. Mustapha Olanrewaju, Aliyu, Doctoral student, Department of Industrial Relations and Personnel Management, Faculty of Management Sciences, University of Ilorin, Nigeria, email: aliyu.om@unilorin.edu.ng

Associate Professor, Akeem Ayofe, Akinwale, PhD, Department of Employment Relations and Human Resource Management, Faculty of Management Sciences, University of Lagos, Akoka, Nigeria, email: aakinwale@unilag.edu.ng

Associate Professor, Adetunji Oluseyi, Shadare, PhD, Department of Employment Relations and Human Resource Management, Faculty of Management Sciences, University of Lagos, Akoka, Nigeria, email: bolawolemsa@gmail.com

Vaida Pilinkienè, Prof., Dr in Social Sciences (Economics), School of Economics and Business, Kaunas University of Technology, K. Donelaičio str. 20, Kaunas, P.O. Box 44239, Lithuania, e-mail: vaida.pilinkiene@ktu.lt;

Alina Stundžienè, Assist. Prof., PhD in Social Sciences (Economics), School of Economics and Business, Kaunas University of Technology, K. Donelaičio str. 20, Kaunas, P.O. Box 44239, Lithuania, e-mail: alina.stundziene@ktu.lt 